Hedina Tahirović-Sijerčić

Komitet eksperata za Evropsku povelju o regionalnim ili manjinskim jezicima

hedina.sijercic570@gmail.com
УДК 811.214.58'373:811.163'373

https://doi.org/10.18485/slavistika.2019.23.1.10

оригинални научни рад

примљено 26.02.2019.

прихваћено за штампу 16.05.2019.

\title{
JUŽNOSLAVENSKE POZAJMLJENICE U ROMSKOM
}

Leksička posuđivanja u romskom jeziku vezana su za historiju migracija Roma, posebno sa jezicima zemalja na čijim su se prostorima Romi najviše zadržavali. Velikim brojem posuđenih leksema na račun romskih leksema kako u svakodevnoj komunikaciji tako i u pismenoj formi, čak i u najjednostavnijim rečenicama, romski jezik dobiva karakteristiku i adekvatnu denominaciju ne samo hibridnog nego i miješanog romskog jezika.

Koristeći se metodom dvostepene semantičke adaptacije Rudolfa Filipovića (1986) u dijalogu sa romskim studijama u oblasti romskog jezika, pronalazim način pristupa istraživanju posuđenica iz južnoslavenskih jezika ${ }^{1} \mathrm{u}$ romskom jeziku, i u isto vrijeme se suočavam sa činjenicom da posuđenice i neologizmi utiču ne samo na očuvanje vitalnosti nego i na gubljenje posebnosti romskog jezika kao posebnog jezika.

Ključne riječi: efekat kontakt jezika, posuđenice, neologizmi, romski jezik, hibrid.

Lexical borrowing in the Romani language relates to the history of Romani migration, especially with the languages of the countries where the Roma have stayed the most. The large number of borrowed lexemes at the expense of the Romani lexemes, both in everyday communication and in written form, even in the simplest sentences, the Romani language acquires a characteristic and adequate denomination not only as hybrid but also as mixed Romani language.

Using the method of two-step semantic adaptation by Rudolf Filipović (1986) in a dialogue with the Romani studies in the area of Romani language, I find a way to approach the research of borrowers from South Slavic languages ${ }^{2}$ in Romani, and at the same time I am confronted with the fact that the borrowers and neologisms influence not only the vitality preservation, but also the loss of the special features of the Romani language as a separate language.

Key words: loanwords, neologisms, Romani language, hybrid, contact langauge effect.

\section{UVOD}

U svakodnevnom kontaktu različitih naroda i njihovih kultura jezici se mijenjaju, neki od njih su ugroženi a neki nestaju jer se njihove zajednice prebacuju na druge veće govorne zajednice ili druge svjetske dominantne zajednice i njihove jezike. Neizbježni efekat kontakt jezika omogućio je razmjenu, poprimanje, adaptiranje i kreiranje velikog broja posuđenica i neologizama, $\mathrm{u}$ isto vrijeme uticao na porast

\footnotetext{
${ }^{1}$ s posebnom pažnjom na bosanski, crnogorski, hrvatski i srpski jezik

${ }^{2}$ especially focused on Bosnian, Montenegrin, Croatian and Serbian language
} 
dvojezičnih i višejezičnih govornika i razvoj dvojezičnosti i višejezičnosti. Takay slučaj je i sa romskim narodom, ${ }^{3}$ njihovom kulturom i jezikom. ${ }^{4}$

Za temu ovog rada važno je ukazati na migracije Roma od X do XI vijeka prema područjima u kojima su se govorili slavenski jezici, rumunjski i albanski jezik, odnosno njihovu pojavu na Balkanu ${ }^{5}$ (Tahirović-Sijerčić 2018b: 43). Posuđivanje leksema iz pojedinih evropskih jezika u romski jezik je uobičajena praksa tokom vijekova, a nužnost tog posuđivanja uzrokovana je malim autohtonim leksičkim fondom, od «oko hiljadu (1000) leksičkih korijena» ${ }^{6}$ (Matras 2002: 21).

Od posebnog značaja za romski jezik, kako ističe Hankok (Hancock 2010), posebno od XVIII do XXI vijeka je efekat kontakt istočnoevropskih jezika a posebno slavenskih jezika.

„Pažljivo ispitivanje i klasifikacija stranih elemenata u raznim dijalektima evropskih Roma omogućili su Miklošiču da zaključi da svi oni pripadaju istom izvoru, da su znatno vreme živeli u okruženju slavenskih jezika grčkog jezika pre nego što su se našli u današnjim staništima“ (Сикимић 2013: 438).

Sasvim je očigledno da je pitanje posuđenica iz drugih jezikâ u romskom jeziku veoma usko povezano sa pitanjima migracija Roma $^{7}$ i politika zemalja u kojima su Romi živjeli i danas žive, a posebno na Balkanu, i one su od posebnog interesa za istraživače. Kako naglašava Lokvud:

,[...] Balkan sačinjava laboratoriju par excellence za romske studije;

[...] Balkanski Romi čine u mnogo različitih aspekata [...] najvažniju romsku zajednicu u svijetu;

[...] Balkanski Romi pokazuju relativno visok stepen kulturne heterogenosti;

${ }^{3}$ Romski narod se sastoji od različitih grupa: Gurbeti, Arlije, Kalderaši, Tamari, Lovari, Manuši, Sinti, Ursari, Sepetari, Kale itd. Mnoge grupe koriste denominaciju Romi, ali ima i grupa koje za sebe koriste denominaciju Cigani, koju druge romske grupe doživljavaju kao pežorativnu.

${ }^{4}$ Romski jezik je klaster od preko 80 romskih varijanti i dijalekata u kojem svaki dijalekat ima svoju perspektivu u stvarnosti zajedno sa različitim jezicima u kontaktu, različitim tradicijama, religijama i navikama (Тахировић-Сијерчић 2018a:112).

5 "The presence of many words adopted from Persian (for example baxt 'luck') and some from Kurdish (vurdon 'wagon') show that the migration must have passed through Iran; Armenian and Greek words (such as kočak 'button' and zumi 'soup') show passage through what is now Turkey; Slavic and Romanian words (dosta 'enough' and raxuni 'smock') indicate a presence in the Balkans" (Hancock 2002: 9)

${ }^{6}$ „The Early Romani legacy amounts to around 1,000 lexical roots [...]” (Matras 2002: 21).

${ }^{7}$ „Analizirajući posuđenice u romskom jeziku, Francz von Miklosich je 1873. rekonstruirao migracijske putove Roma. Miklosich je dokazao da su perzijski i armenski utjecaji prisutni u svin romskim dijalektima indikator njihovog boravka u Perziji i Armeniji prije dolaska u Malu Aziju. Velik broj srednjovjekovnih grčkih riječi koje koriste gotovo sve romske skupine u Europi poveza。 je s dugotrajnim boravkom u Bizantskom carstvu. Utjecaj slavenskih jezika povezao je s boravkom na Balkanu, a određen broj rumunjskih riječi u romskim dijalektima u središnjoj i sjevernoj Europi povezao je s prolazom Roma kroz Rumunjsku“ (Demir 2017: 38-39).
Južnoslavenske pozajmljenice u romskom

[...] Romi iz šest balkanskih zemalja predstavljaju 60\% svih Roma svijetu i oni govore romski jezik ${ }^{8}$ (Lockwood 1985: 91-99)“.

Da bismo odgovorili na pitanje južnoslovenskih pozajmljenica u govorima balkanskih Roma, neophodno je, prije svega, osvrnuti se na opšte poznatu definiciju posuđenice koja podrazumijeva leksičko posuđivanje, pri čemu se riječi usvajaju iz jednog ili iz više jezika u drugi jezik (Тахировић-Сијерчић 2018a: 117), kao i na definiciju neologizma koja podrazumijeva jezičku pojavu koja je nastala za vrijeme govornikovog života. Isto tako neophodno je razmotriti razmišljanja Rajka Đurića koji u Standardizaciji romskog jezika govori o romskim dijalektima u bivšoj Jugoslaviji ${ }^{9}$, i tvrdi da oni „sadrže neuporedivo više istovjetnih, sličnih i zajedničkih elemenata, nego onih po kojima se međusobno razlikuju“ (Đurić 2012: 39), kao i na razmišljanja Ranka Bugarskog koji govori o kontakt jezicima odnosno o većinskim jezicima na ovim prostorima navodeći da ,[d]ok su slovenački i makedonski nastavili na svom putu“"10, za bosanski, crnogorski, hrvatski i srpski je ,[...] u jezičkim terminima[...] teško govoriti o četiri različita jezika [...]"11 (Bugarski 2012: 230-231).

Moja tvrdnja je, da su u romskom jeziku, odnosno dijalektima i govorima romskog jezika na prostoru bivše Jugoslavije, zahvaljujući konstantnom i intenzivnom kontaktu sa bosanskim, crnogorskim, hrvatskim i srpskim jezikom posuđenice u romskom jeziku postale neophodnost koja u isto vrijeme utiče na održavanje lingvističke vitalnosti romskog jezika (Тахировић-Сијерчић 2018a: 111), ali i na „uzrokovanje prijetnje gubljenja njegove posebnosti ${ }^{12}$ (Cronin 1995: 89)“ (Tahirović-Sijerčić 2018c: 136) kao jezika.

\section{TEORIJSKI OKVIR}

Komunicirajući, romski govornici nesvjesno potiskuju, mijenjaju i zaboravljaju izvorne romske lekseme sa leksemima jezika iz kontakta, a njihov jezik dobiva karakteristiku miješanog (mixed) jezika. ${ }^{13}$

Navodeći Vindišove (Ernst Windisch) kriterije miješanog jezika, Filipović vid miješani jezik u svakom jeziku u kojemu se: ,1. strane riječi upotrebljavaju na račun domaćih, 2. postojeće domaće riječi kojima se opisuju predmeti zamjenjuju stranim, 3 . javlja veliki postotak posuđenica, 4. upotrebaljavaju posuđenice i u najjednostavnijim izrazima i rečenicama, 5. osim posuđenica imenica upotreblavaju i glagoli, pa čak

8 “" [...] the Balkans constitute a laboratory par excellence for Gypsy studies, [...] Balkan Gypsies constitute in a number of different respects [...] the most important Gypsy community in the world [...] Balkan Gypsies show a comparatively high degree of cultural heterogenity, [...] Roma from six Balkan countries represent $60 \%$ of all Roma in the world and they speak the Romani language
(Lockwood 1985: 91-99)".

${ }^{9}$ Bosna i Hercegovina, Crna Gora, Hrvatska, Makedonija, Slovenija i Srbija

10 "[w] hile Slovenian and Macedonian proceeded on their paths [...]" (Bugarski 2012: 230).

11 "[...] in linguistic terms $[\ldots]$ difficult to talk about four distinct languages [...]" (Bugarsk 2012: 231)

12 "it could cause a threat of its distinctiveness (Cronin 1995: 89) ".

13 'Romani mixed language'

Славистика XXI"/1 (2019) 
brojevi i morfološki oblici te drugi dijelovi rečenica stranog porijekla“ (Filipović 1986: 21).

Navedeni kriteriji mogu se označiti kao značajne karakteristike romskog jezika kao „miješanog": više je nego očito da Romi u velikoj mjeri koriste strane riječi na račun autohtonih ${ }^{14}$; da postojeće romske riječi zamjenjuju stranim; ${ }^{15}$ da romski sadrž veliki postotak posuđenica kako u svakodnevnoj komunikaciji tako i u pisanoj riječi i prevođenju; da se u romskom upotrebljavaju posuđenice čak i u najjednostavnijim izrazima i rečenicama ${ }^{16}$; i da se osim posuđenih imenica upotrebljavaju i glagoli $^{17}$ kao i sintagme stranog porijekla ${ }^{18}$.

Specifičnost romskog jezika i upotrebe leksičkih, gramatičkih, morfoloških pravopisnih oblika iz južnoslovenih jezika dovode romski jezik u ovisnost oslanjanja na južnoslovensku leksiku i jezičku strukturu. Između ostalog „zahvaljujući komunikaciji na većinskom/im jeziku/cima Romi kreiraju nove romske riječi dodavanjem sufiksa iz sopstvenog romskog dijalekta“" (Тахировић-Сијерчић 2018a:116).

Veliki broj posuđenih leksema u romskom jeziku doživio je primarnu semantičku adaptaciju. Njihova nulta semantička ekstenzija u kojoj nema razlike u značenju između jezika davaoca i jezika primaoca (Filipović 1986: 65), „podrazumijeva preuzimanje tuđe riječi u onom značenju kakvo je zahtijevao trenutni jezički kontekst i potrebe jezika primaoca“ (Vajzović 1999: 167). Primjere za primarnu semantičku adaptaciju nalazimo u slučaju leksema životo, miro, narodo itd. I pored toga što navedeni leksemi sadrže romski sufiks -o, ov leksemi zadržali su u romskom jeziku isto značenje koje oni imaju u jezikudavaocu. Bitno je napomenuti da su navedeni leksemi, kao i mnogi drugi iz

${ }^{14}$ Da navedem nekoliko: iz kontakt jezika u romskom koriste jastuko, umjesto romske imenice šerand; pridjev šaren iz kontakt jezika u romskom upotrebljavaju šareno, umjesto romskog pridjeva kotorvalo; imenicu corba iz kontakt jezika koriste umjesto romske imenice zumi; u romskom koriste kreveto -'krevet' umjesto romskih imenica sovardo, sovljardo, buhljardo, pato; imenica čaš 'čaša' u romskom jeziku koristi se umjesto romske rječi tahtaj ili taxtaj, w ovisnosti od romsko riječi cahra;

${ }^{15}$ Imenicu lampa koriste u romskom kao lampa i lampava umjesto jagali ili lumeri (ovdje je bitno napomenuti da se riječ jagali koristi i za pištolj i pušku). Drugo značenje ova riječ dobiva ukoliko govornici, kao što je slučaj u romskoj mahali Gorica u Sarajevu, koriste pridjev crvena uz imenicu lampa i pored toga što svi znaju da je na romskom crven loli. U ovom kontekstu crven lampa/lampava znači ,kurva'. Međutim i riječ kurva se u romskom koristi iako ima mnogih drugih romskih riječi za taj pojam (xalavdi, karxali, phabardi, phirni, phiravni itd. ), a ove su riječi n romskom uglannom izvedenice iz romskih glagola (jesti, goriti, lutati itd) odn. (ona koja jede, koja gori, koja luta itd.

${ }^{16}$ Voliv tut! 'Volim te!' a na romskom bi trebalo da glasi Kamav tut!; Beš mirno! 'Sjedi mirno!' Dema kantica! 'Daj mi kanticu!' a na romskom bi trebalo da glasi Dema kaćuno! So manges/h majmuno? 'Šta želiš majmune?', a na romskom bi trebalo da glasi So manges/h pojralo?; Na kurvo! 'Bježi kurvo!', što bi na romskom trebalo da glasi Naš xalavdi! ili Naš pharadi! itd.

17 „Позајмљенице су глаголи trebel 'требати' из српског (док би варијанте trubul, trubuj истог глагола могле бити румунски славизам) и глагол тияаj 'морати', који је у ромски стигао посредно из немачког језика, а преко румунског“ (Ђурић 2018: 272)

${ }^{18}$ I dej spremisarda o ručko - 'Majka je spremila ručak'; Von pisinen bari knjiga. - 'Oni pišu veliku knjigu'; Želinava jekh srebreno BMW te vozinav leh ando Saraj - 'Želio bih jednog srebrnog BMWa da ga vozim u Sarajevo'.
Južnoslavenske pozajmljenice u romskom

163

slavenskih jezika, poput mirno 'miran', sloboda 'sloboda', puška 'puška', zeleno 'zelen' i drugih, adaptirane posuđenice koje nisu pretrpjele semantičku adaptaciju čak ni tokom migracija

Za ilustraciju transformacije pozajmljenica poslužiće primjeri iz rječnika govora Roma Kalderaša, migranata u Sjevernoj Americi (Kanada, SAD), uglednog savremenog romologa Ronalda Lija (Ronald Lee, 2010).

Primjera radi navest ću pridjev miran, naveden u Romani Dictionary: Kalderash - English (Lee 2010), koji na romskom (mirno) može imati funkciju i pridjeva priloga: «mirno pridjev 1) miran, tih; Besh mirno! Smiri se!/Budi miran! 2) prilog mirno, tiho; Phirdyas mirno opre l' skeri. Hodao je tiho uz stepenice“" (Lee 2010: 204), jednako kao i u južnoslovenskim jezicima. ${ }^{19}$

Za razliku od primarne, sekundarna semantička adaptacija podrazumijeva proširenje značenja koje je uvjetovano dužom upotrebom posuđenica u jeziku primaoca kao i djelimična i/ili potpuna semantička nepodudarnost odnosno pogoršanje značenja (Filipović 1986: 65). Kod sekundarne adaptacije samo je jasan njen postanak, a krajnja vremenska granica promjena koje su nastale na fonološkom, morfološkom i semantičkom nivou ${ }^{20}$, ne može se odrediti (1986: 58-65).

Kod vrlo malog broja slavenskih posuđenica došlo je do proširenja (ekstenzije) značenja. Potpuna semantička nepodudarnost odnosi se na potpuno novo značenje u kojem nema nikakve podudarnosti sa prvobitnim značenjem riječi. Ova pojava je skoro pa nepoznata u slučaju obrazovanih romskih govornika u regionu, dok se u slučaju manje obrazovanih romskih govornika, koji najčešće žive u segregaciji i koji su marginalizovani, pojavljuje vrlo često, i uzorkovana je nedovoljnim poznavanjem većinskog, odnosno kontakt jezika, uz korištenje riječi bez tačnog shvatanja njihovog značenja. ${ }^{21}$

Međutim, kod Roma migranata zabilježeni su ovakvi slučajevi i mogu se zapaziti u govoru kako davnih tako i skorašnjih migranata. Potreba za novom riječi se, kako navodi Filipović „može zaodovoljiti jednim od triju postupaka: a) tvori se nova riječ od postojećih elemenata jezika; b) posuđuje se riječ iz nekog drugog stranog jezika; c) mijenja se značenje neke postojeće stare riječi u jeziku ili joj se pored starog dodaje novo značenje“"(Filipović 1986: 158).

Ponovo ću navesti primjer iz rječnika Romani Dictionary: Kalderash - English (Lee 2010). Naime, autor u svom rječniku navodi imenicu ženskog roda na romskom nanúla dajući joj značenje 'čizma', te navodi i množinu ove imenice na romskom

${ }_{194}$ "mirno adj 1) calm, peaceful, quiet, silent, tranquil; Besh mirno! Calm down!/Stay quiet! 2) $a d v$ calmly, peacefully quietly, silently; Phirdyas mirno opre l' skeri. He walked quietly upstairs " (Lee 2010: 204).

${ }^{20}$ Prema tim nivoima imenovani su procesi: transfonemizacija, transmorfemizacija i semantičko posuđivanje (Filipović 1986: 58-65).

${ }^{21}$ Navest ću primjer sa društvnih mreža youtube.com. Snimatelj se nalazi u romskom naselju razgovara sa Romkinjom. Ona govori da joj sin „Ne može dobiti poso“. Snimatelj je pita: „Sta je po struci?" Ona mu odgovara: „Po struci je Rom isto ko i ja“. Očito je da ova Romkinja ne poznaje značenje riječi 'struka' 1 da nije razumjela pitanje. 
nanúlya (Lee 2010: 214). ${ }^{22}$ Očito je da je kod Roma migranata došlo do pomjeranja značenja korišćenja ove riječi. ${ }^{23}$

Isto tako, autor navodi posuđenicu, imenicu ženskog roda 'rijeka/reka' kao romsku imenicu muškog roda réko u značenju 'jezero' i 'potok' (Lee 2010: 252). ${ }^{24}$ Imenica je izgubila svoje prvobitno značenje 'rijeke/reke' a njeno prošireno značenje 'jezero' 'potok' uzrokovano je njenim potpuno slobodnim korištenjem u romskom jeziku kao 'velike količine vode'.

Bitno je naglasiti da semantičke promjene, kako navodi Filipović, nastaju zbog šest uzroka: lingvističkih, historijskih, socijalnih, psiholoških, stranih uticaja kao uzroka semantičke promjene i potrebe za novom riječi kao uzroka semantičke promjene (Filipović 1986: 158).

Stalna praksa govornika romskog jezika da koriste posuđene riječi i neologizme iz dominantnih jezikâ, odnosno jezika u kontaktu odražava neravnotežu moći koja postoji između romskog i većinskih jezika i signalizira veoma jaku dominaciju većinske zajednice na Rome koji su historijski etnička grupa ili manjina gdje god da žive. Korištenje leksema iz drugih jezika jasan je element hibridnosti u kontekstu gdje postoji usidrena svijest jezičkog i kulturnog miješanja (Tahirović-Sijerčić 2018b:30).

Pored forme hibridnosti u romskom jeziku prisutna je i forma mimikrije (TahirovićSijerčić 2018c: 133) koju karakteriše svakodnevno korištenje jezika od strane romskih govornika uz korištenje gramatike i pravopisa većinskih jezika u zemaljama u kojima žive. Efekat kontakt jezikâ na romski jezik je više nego dominatan a

„[...] Borecki i Igla priznaju da nema nikakvog razgovora na romskom bez velikog broja srpskohrvatskih reči (Boretzky/Igla 1994:X) te da su za razumevanje savremenog romskog potrebna dva rečnika: rečnik romskog jezika i rečnik kontaktnog jezika [...]““ (љ.Ђypић 2018: 265).

\section{POSUĐENICE - SVAKODNEVNA KOMUNIKACIJA I PISANA RIJEČ}

Zajednički elementi romskog i kontakt jezikâ ukorijenjeni su u posuđenim riječima i neologizmima čije prisvajanje i adaptiranje dovodi mnoge prosječne govornike dilemu da li je određeni leksem romskog porijekla, ili je posuđenica ili neologizam (Тахировић-Сијерчић 2018a: 118). Primjera radi navest ću nekoliko leksema slavenskog porijekla: 'miro', 'narodo', 'zeleno', 'mačka', 'životo', 'oblako' kao i leksem turskog porijekla 'jastuko' kojem je, sasvim moguće, u ovom slučaju bosansko-hrvatsko-srpski jezik poslužio kao transfer.

\footnotetext{
22 "nanúla $n f$ 1) boot: pl nanúlya" (Lee 2010: 214).

${ }^{23} \mathrm{U}$ toku mog života kao migranta u Kanadi, Toronto, (1997), radila sam zajedno sa Ronald Liom u tamošnjoj romskoj organizaciji i uređivali smo zajedno dvojezični romski magazin „Romano lil““. Skrenula sam mu pažnju na značenje riječi , nanula' a on je bio sumnjičav i nije mogao da shvati da Skrenula sam mu pažnju na značenje riječi , nanula a on je bio sumnjičav i nije mogao da shvati da
je to neka druga vrsta obuće a ne čizma. 2013. godine ponovo sam posjetila Toronto i moje prijaje to neka druga vrsta obuce a ne čizma. 2013 . godine ponovo sam posjetila Toronto i moje prijaniti odgovor na koji način je došlo do toga da je ,nanula' postala ,čizma'.

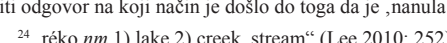

Južnoslavenske pozajmljenice u romskom

165

Nakon sprovedene ankete ${ }^{25}$, od 30 ispitanika, prosječnih govornika romskog jezika, u slučaju riječi ‘miro' svih 30 ispitanika smatra da je romskog porijekla; u slučaju riječi 'narodo' svih 30 ispitanika smatra da je romskog porijekla; u slučaju pridjeva 'zeleno' svih 30 ispitanika smatra da je romskog porijekla; u slučaju riječi 'mačka' svih 30 smatra da je posuđena riječ, ali uz pokušaje prisjećanja na moguće romske riječi za mačku koje se nisu sjetili; u slučaju riječi 'životo' 23 ispitanika smatra da je u pitanju romska riječ, dok 7 smatra da je posuđenica navodeći romsku riječ 'džuvdipe' koju su koristili njihovi dede i nane a rijetko njihovi roditelji; u slučaju riječi 'oblako' 25 smatra da je romska riječ dok 5 smatra da je posuđenica pokušavajući se sjetiti prave romske riječi koju nisu mogli dokučiti; i u slučaju riječi 'jastuko' 10 ispitanika smatra da je to romska riječ dok 20 smatra da je posuđenica navodeći romsku riječ ‘šerand' koju su koristili njihovi dede i nane, roditelji pa čak i oni sami u rijetkim slučajevima.

Ova anketa je dovela do pretpostavke da su riječi 'miro', 'narodo', 'zeleno', 'mačka', 'oblako' posuđenice koje se u romskom jeziku koriste u vremenskom periodu manjem od devedeset (90) godina, a da su riječi ‘životo' i ‘jastuko' posuđenice koje se koriste $u$ vremenskom periodu od oko trideset (30) godina.

Da bi ustanovila njihovo vrijeme provedeno u romskom jeziku, konsultovala sam Franca Miklošića ${ }^{26}$ (1813-1891), filologa i jednog od utemeljivača romologije kao nauke, i njegove Beiträge zur Kenntniss der Mundart der Zigeuner in Galizien, in Sirmien und in Serbien. Mit einem Anhange über den Ursprung des Names "Zigeuner". Vorgelegt in der Sitzung am 9. Februar 1876.

U rječniku ovog djela nalaze se riječi oblako (1876: 28) i óblako (1876: 48), zelen, zélino (1876: 46), narodos (1876: 12) i národo (1876: 27), i mačka (1876: 11 27, 40). Riječi ,miro“ i ,životo“ nisu sadržane, niti ,jastuko“ (ali njihov izostanak sa ovog malog spiska romskih riječi ne znači i da nisu bile u upotrebi). Umjesto ,jastuko' koristi se romska riječ šerand $(1876: 44,53)$.

Zahvaljujući Miklošiču i njegovoj leksikografskoj potvrdi posuđenica oblako, zeleno, narodo i mačka, može se sa sigurnošću tvrditi da su se one koristile u romskim gurbetskim govorima prije 143 godine, uzimajući datum objavljivanja ovog rječnika.

Zatim sam konsultovala Srpskohrvatsko-Ciganski Rečnik (Romane Alava) akademika, lingviste i romologa Rada Uhlika $(1889$ - 1991) iz 1947. godine. Vremenska razlika od objavljivanja rječnika do današnjih dana je 72 godine. Za riječ ,mir‘ naveo

${ }^{25}$ Anketa je rađena u sarajevskim romskim naseljima Sokolović kolonija u kojoj živi čergaška skupina Roma (koja je u međuvremenu takođe sjedilačka odnosno sedentarna) i Gorica u kojoj žive starosjedilački Romi (bešavne ili thaneske - 'sjedilački' , 'mještanski'). Anketa je rađena u febr 2019. godine, a ispitano po 15 govornika u svakom naselju odnosno u svakoj mahali. Starosna dob ispitanika je od 19-69 godina Pitanja u anketi. Da li su riječi 'miro' 'narodo' 'zeleno' 'mačka',

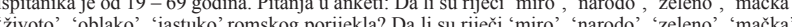

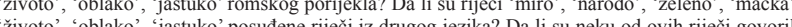
"Zli

${ }^{26}$ Lingvista Dieter Halwachs omogućio mi je pristup Miklošičevim djelima i rječniku Norberta Boreckog i Birgit Igla, te koristim priliku da mu se u to ime zahvalim i da mu izrazim posebno poštovanje za njegov rad i doprinos romologiji. 
je njenu romsku leksemu (laćhipé m., šukaripé m.) (1947: 81); za riječ ,narod‘ takođe (them m.) (1947: 88); za ,zelen' (__ _ ; vbnato) (1947: 188); za riječ , mačka' takođe postoji autohtoni termin (cicni ž., mišijakóngji ž.; kandojengji ž.) dok je za riječ ,mačak' navedena pozajmljenica (mačijáko m.) (1947: 78). Lekseme ,oblak' nema u rječniku ali postoji njena množina: ,oblaci (crni)' za koju daje autohtonu romsku riječ (kalipé m., kalimáta ž.) (1947: 95) što znači 'crnina' a može da znači i 'tama'. Za riječ ,život' navedena je romska riječ uz pozjamljenicu iz rumunjskog jezika (dživindipé m., džumindipé m.; trajo m., trajipe m., džuvipe m.) (1947: 193). Romska riječ postoji i za ,jastuk' (šoránd m.; šeránd m.) (1947: 60).

Kada sam uporedila ove riječi sa Uhlikovim Srpskohrvatsko-romsko-engleskom rječniku (Romengo alavari) iz 1983. godine došla sam u situaciju da razmišljam da li je Uhlik možda namjerno izostavio posuđenice i riječi iz svakodnevnog govora prosječnih romskih govornika.

Po Uhliku riječi ,miro', ,narodo', ,zeleno', ,mačka', ,oblako', ,životo' ,jastuko' se vjerovatno uopšte nisu koristile prije 72 godine ali niti prije 36 godina kod bosanskih Gurbeta na čijem je govoru i zasnovan ovaj rječnik. Naravno, ovakav romski lekički fond kod Uhlika je u potpunom neskladu sa podacima iz sprovedene ankete. Da li je i Uhlik, kao što su to i autori rječnika nastalih u posljednjih desetak godina, ${ }^{27}$ namjerno izostavio posuđenice? Kako navodi $\mathrm{Lj}$. Đurić:

„Ispitani rečnici uglavnom izbegavaju pozajmljenice. (...) Na terenskom istraživanju u Vajskoj (maj 2016), tim Balkanološkog instituta SANU pitao je informatore kako se kaže ,oblak“, i odgovor je bio oblako. Da li bi reč oblako trebalo navesti u rečniku romskog jezika? Kako rešiti status onih reč koje se pojavljuju kao rezultat jezičkog kontakta? (...) Ako se pozajmljenice izbacuju iz rečnika, možemo postaviti pitanje da li je rečnik pred nama onda rečnik romskog jezika - šta god taj romski jezik podrazumevao - ili rečnik izbornih reči romskog jezika (v.o ovom pitanju i Lichtenberk 2003“ (Љ. Ђурић 2018: 265).

Nakon Uhlikovog rječnika konsultovala sam rječnik Norberta Boreckog i Birgite Igla (Norbert Boretzky, Brigit Igla) iz 1994. godine koji djelimično sadrži posuđenice koje su se u vrijeme nastanka ovog rječnika često upotrebljavale. Bitno je napomenuti da se ovaj rječnik jednim dijelom oslanja na, u to vrijeme već postojeći, rječnik Radeta Uhlika (Сикимић 2013: 32).

Traženje posuđenih riječi ,miro', ,narodo', ,zeleno', ,mačka', ,oblako', ,životo 1 ,jastuko " urodile su plodom. Pronađene su imenice národo (1994: 194), máčk (1994: 172), óblako (1994: 199), živóto (1994: 308), i pridjev zéléno i imenica

${ }^{27}$ Kajtazi, Veljko. Romano-kroacijako thaj Kroacijako-romano alavari // Romsko-hrvatski hrvatsko romski rječnik. Zagreb: Odjek za orijentalistiku Hrvatskoga filološkog društva i „Kal Sara”, Udruga za promicanje obrazovanja Roma u Republici Hrvatskoj, 2008.;Tahirović Sijerčić, Hedina. Bosansko-romski i romsko-bosanski rječnik // Bosnaki-Rromani thaj Rromani-Bosnak alavari. Mostar: Federalno ministarstvo obrazovanja i nauke, 2010; Krasnići, Alija. Angluno rromano-srbikano, srbikano-rromano alavari / Prvi romsko-srpski, srpsko-romski rečnik. Kraljevo: Librocompany, Subotica: Amaro drom - Naš put, 2012; Haliti, Bajram. Srpsko-romsko-engleski rečnik sa gramatikom. Beograd: Beoknjiga, 2012.
Južnoslavenske pozajmljenice u romskom

zelenipé (1994: 304). Posuđenica ,jastuko“ ne pojavljuje se u sadržaju rječnika kao takva nego u svom izvornom značenju, šérand [šərand, šorand, šorund] (1994: 269). Imenica odnosno posuđenica ,miro" nije sadržana u rječniku.

Da bih prikazala sadašnju situaciju upotrebe posuđenica, konsultujem i nedavno objavljeni Romsko-srpski rečnik knjaževačko-gurbetskog govora (2017) u kojem autorke Ćirković i Mirić ukazuju kako na romske riječi tako i na pozajmljene riječi iz srpskog jezika i na etnografizme na romskom i na srpskom jeziku. Autorke takođe ukazuju i navode listu posuđenih riječi koje su izostavljene iz rječnika naglašavajući da su ,[p]ozajmljene reči postale sastavni deo leksičkog fonda govornika i mahom su adaptirane u romski morfološki sistem (...)“(Ćirković i Mirić 2017: 10).

Vodeći se tragom već navedenih posuđenica ,miro', ,narodo', ,zeleno', ,mačka', ,oblako', ,životo' i ,jastuko' u rječniku ne pronalazimo imenice ,mir' niti ,miro nego glagol, ka pomirol pe" (će se pomiriti) (2017: 86); ne pronalazimo pridjev zeleno' niti imenice mačka' $i$ oblako"; ali pronalazimo imenice ,narodo' (2017: 71) i , životo“ (2017: 109) a imenica ,jastuko‘ koja je već bila najavljena u predgovoru ovog rječnika kao izostavljena riječ iz liste posuđenih riječi, ne nalazi se u sadržaju u Romsko- srpskom rečniku knjaževačkog gurbetskog govora (2017: 10).

Činjenica je da su posuđenice u romskom jeziku ili adaptirane odnosno prilagođene i/ili neadaptirane odnosno neprilagođene. Nekoliko primjera korištenja posuđenica neologizama omogućit će uvid u ovu problematiku i nadam se potaknuti interese za istraživanjem posuđenica u romskom jeziku.

Primjer 1: Upotreba posuđenica i neologizama u svakodnevnoj komunikaciji

Pe kreveto si jekh jastuko. / Na krevetu je jedan jastuk.

Me džav ande škola. / Ja idem u školu.

Mo čhavo si les o kompjutero i lap top./ Moj sin ima kompjuter i lap top.

I dej spremisarda e čhave pala bijav./ Majka je spremila djecu za svadbu.

Akhar sine prdal pe cesta. / Pazi sine preko ceste.

Kate sasa saobraćajka. / Tu je bila saobraćajna nesreća.

Na džanav so ćerel dilo, ako si mulo ako si ande robija ili ande bolnica./ Neznam šta radi budala, da li je mrtav, da li je na robiji ili u bolnici.

Trubuj i mora te džanav rezultatura katar mo doktoro./ Treba i mora da znam rezultate od mog doktora.

Prestindja te kuvel jekh srce savo sasa legenda amare muzikake./ Prestalo je da kuca jedno srce koje je bilo legenda naše muzike.

Amaro narodo mangel miro i mogućnipe pala životo./ Naš narod treba mir i mogućnost za život. ${ }^{28}$

\footnotetext{
${ }^{28}$ Podebljane riječi u romskom jeziku su posuđenice iz većinskih jezika.
} 
168 Hedina Tahirović-Sijerčić

U ovakvoj situaciji romski jezik kao manjinski jezik ${ }^{29}$, a u okvirima uobičajene prakse korištenja jezika u svakodnevnoj komunikaciji, ,postaje ogledalo dominantnog jezika (Cronin 1998: 147)“ 30

Primjer 2:

A. bosansko-hrvatski-srpski-crnogorski jezik: Dobro došli na našu web stranu na romskom jeziku - kliknite ovdje. Ovdje možete da birate dobru muziku. Želimo vam ugodan vikend.

Prevod - romski jezik: Šukar avilen pe amaro web sajto pe romani ćhib - klikninen akate. Kate birin te šunen laćhe romane gilja. Ame mangas tumen ugodni vikendi.

B. bosansko-hrvatski-srpski-crnogorski jezik: Ono što može da bude od koristi je da socijalni mediji danas rade jedan koncept gdje je čovjek uvijek prisutan diskutuje, a time potpomaže jačanju identiteta mnogih ljudi.

Prevod - romski jezik: Ande jek so shaj avas zgodni si socialni mediji adje kerzilas jek koncepto kaj manush si kothe, diskutulin kado, thaj jekh kotor anda zurales buthe manushengo identiteto.

C. bosansko-hrvatski-srpski-crnogorski jezik: (...) niz aktivnosti koje treba poduzeti i koje moraju imati u vidu i uzeti u obzir postojeće stimulativne mjere aktivnosti u oblasti zapošljavanja koje su dale određene rezultate.

Prevod - romski jezik: (...) nizo aktivnosturengo save trubuj te poduzmin pe save mora te aven an uvid $i$ te lol an obzir već postojime stimulativni mjere te aktivnostura an oblastura zapošljavanjeko save dje određeni rezultatura. ${ }^{3}$

U Primjeru 2 korištenje posuđenica i neologizama stvara iskrivljenu, pa i smiješnu sliku romskog jezika u ogledalu dominatnih jezika. Ta slika reflektuje ozbiljn društveno-ekonomsku, obrazovnu i lingvističku neravnotežu moći između romske i većinskih zajednica, a ,prisustvo, odnosno odsustvo reči iz leksičkog fonda nekog idioma može poslužiti kao važan pokazatelj različitih društveno-istorijskih i kulturnih okolnosti u kojima se jezik razvija“" (Ćirković i Mirić 2017, 10 ). Romski jezik je, uprkos društveno-ekonomskoj marginalizaciji Roma i njihovoj borbi za preživljavanjem, preživio samo u kontekstu dvojezičnosti i/ili višejezičnosti njegovih govornika.

${ }^{29}$ Prema European Charter for Regional or Minority Languages, "regional or minority language means languages that are: (i) traditionally used within a given territory of a State by nationals of that State who form a group numerically smaller than the rest of the State's population; and (ii) differen from the official language(s) of that State; it does not include either dialects of the official language(s) of the State or the languages of migrants" $<$ https: $/ /$ rm.coe.int $/ 168007 \mathrm{bf} 4 \mathrm{~b}>10.01 .2019$

${ }^{30},[\ldots .$.$] become mirror-image of the dominant language“ (Cronin 1998, p. 147)$

${ }^{31}$ Podebljane riječi u romskom jeziku su posuđenice iz većinskih jezika.
Južnoslavenske pozajmljenice u romskom

Ista situacija je i kada je u pitanju ,romska književnost $[k o j a]$ se može smatrat tipičnom 'lokacijom' heteroglosije, jer se uglavnom zasniva na hibridizaciji različitih jezika i književnosti bez obzira na jezičke i nacionalne granice“32 (Toninato 2004: 335). Efekat kontakt jezika u književnom pisanju je vrlo bitno napomenuti posebno zbog toga što romski jezik već sadrži važan sloj leksičkih i sintatičkih elemenata posuđenih iz drugih jezika sa kojima je najviše u kontaktu. „U isto vrijeme ta dominacija jezika nad romskim jezikom, kreacija neologizama i upotreba posuđenica potpomogla je razvijanje romske književnosti koja je „lingvistički hibrid“ (Toninato 2014:71) kako u nacionalnim tako i u internacionalnim okvirima“" (Тахировић-Сијерчић 2018a: 117). ${ }^{33}$

Primjer 3:

A. Romski jezik:

Gazisarde romengi violina

ačile ognjišta romane

e jag o dimo

ando oblako vazdinjalo. ${ }^{34}$

Prevod:

Zgažena romska violina

ostala ognjišta romska

vatra $\underline{\operatorname{dim}}$

u oblak se diže.

B. Romski jezik : Mo anav sasa Mehmed. Bijandilem thaj dzivisardem ande Bosna. Cherdem xarkumache sheja, kazane i kotlove. (...) Rodav miro. (...) Grast boldisarda e plave delese. Me boldisardem e plave pajese.

32 " $[\ldots] \mathrm{R}$ omani literature could be regarded as a typical 'site' of heteroglossia, as it is largely based on the hybridization of different languages and literatures regardless of linguistic and national boundaries" (Toninato 2004: 335)

33 "Once, I talked to Meli Depner, a translator from Germany, who translates Romani poets into German. While contacting me and consulting about some words she needed to translate from Romani I was realized that the words about whose meaning she asked me were loanwords from Serbian and found in Romani poems she translated. These words are nowdays rearly used in Serbian but Roma still use them in Romani; like šifonjer which means chiffonier, [or from Bosnian found in Romani like kavonozo which means jar, sinija which means low round table, etc.]. After many consultations she asked me how to study Romani which is spoken in former Yugoslavia, an my answer was that she should first learn one of the majority languages Serbian, Bosnian, Croatian or Montenegrin" (Tahirović-Sijerčić 2018b: 185).

${ }^{34}$ Strofa pjesme Zgažena romska violina romskog pjesnika Rasima Sejdića (1943-1981) iz Bosne i Hercegovine. Pjesma u cjelosti prvi put objavljena u njegovoj zbirci pjesama Rasim poeta zingaro 1987. godine (Rho: Publi and Press) u Italiji. Za potrebe ovog rada korištena strofa objavljena u Antologiji romske poezije koju je pripremio Dragoljub Acković 2012. godine u Sarajevskim sveskama N. 39/40. Prevela, za potrebe ovog rada Hedina Tahirović-Sijerčić.

Славистика XXIII/1 (2019) 
Prevod: Ime mi je bilo Mehmed. Rodio sam se u Bosni. Kucao sam kazane kotlove od bakra. (...) Tražim mir. (...) Konj se vratio spektru plavih nijans neba. Ja se vratio spektru plavih nijansi vode..$^{35}$

U primjeru 3 pjesnici stvaraju svoja djela na romskim dijalektima u jezičkom prostoru kojim dominiraju moćni jezici sa kojima je njihov romski dijalekt u kontaktu. Korištenje posuđenica kao integrirani dio njihovom kreativnom radu ni u kom slučaju ne umanjuje vrijednost njihovog pjesničkog izraza i njihove krativnosti. U ovakvoj jezičkoj situaciji možemo reći da posuđenice 'ostavljaju svoj trag' ne samo na romsku čitalačku publiku, koja ih i sama možda koristi ili će ih vremenom koristiti, već i na neromsku publiku koja u prepoznatim riječima u romskom tekstu očekuje da, u prevodu ili autoprevodu, sazna u kom kontekstu su te riječi korištene. Kako navodi Tahirović-Sijerčić ,prevod i autoprevod su važne i moćne komponente koje u današnje vrijeme utiču na način očuvanja lingvističke vitalnosti romskog jezika“ (Тахировић-Сијерчић 2018а: 125).

Međutim, nije ni rijedak slučaj da u želji za izbjegavanjem posuđenica neologizama iz većinskih jezika koriste posuđenice i neologizme iz već postojećih romskih dijalekata, te dizajniraju lekseme za svoje potrebe kao u slučaju „Kurtjadevog (Courthiade) dizajn-romskog“ ${ }^{36}$ Primjera radi navest ću najčešće korišteni pridjev 'internacionalan' za koji se koristi dizajn-romski pridjev maškarthemutno. Pridjev sačinjava prijedlog 'između - maškar' i pridjev ‘themutno - državni’ koji je izveden od imenice 'država' - 'them' (Tahirović-Sijerčić 2018b: 48).

Primjer 4: Kreiranje novih leksema

\section{A. Romski jezik:}

Adjive si Maškarthemeski konferencija pala romani čhib. Amaro narodo, amaro glaso $\underline{1}$ amari čhib mora te $\underline{\text { živinen. }}$ Skupo si organizirime uzo ažutipe katari biprofitnikani organizacija pala manušvalikane čačipa, Arakhavne forutnenge čačipa. ${ }^{37}$

Prevod:

Danas je međunarodna konferencija o romskom jeziku. Naš narod, naš glas i naš jezik mora da žive. Skup je organizovan uz podršku neprofitne organizacije za ljudska prava, Branioci građanskih prava.

B. Romski jezik:

Evropako čartero pa regionalni vaj minoritetonge šiba thaj eksplikacijako raporto. But berš diferentni organur ande Evropako Saveto briginas pa e

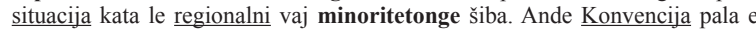

\footnotetext{
${ }^{35}$ V.: Tahirović-Sijerčić (2010: 87-89).

${ }^{36}$ V.: Design-Romani by Courthiade (Zatreanu and Halwachs 2003: 13).
}

Protekcija kata' I Manušikane Čačimata thaj kata 'I Fundamentalni Slobode arakhadol ando Artiklo 14 o principo kata e non-diskriminacija.

\section{Prevod:}

Evropska povelja o regionalnim jezicima i jezicima manjina - Izvještaj sa obrazloženjem. Različita tijela unutar Vijeća Evrope godinama izražavaju zabrinosti zbog položaja regionalnih ili jezika manjina. Tačno je da Konvencija za zaštitu ljudskih prava i osnovnih sloboda u članu 14. propisuje princip nediskriminacije.

$\mathrm{U}$ primjeru 4 A kombinovanjem i kreiranjem te upotrebom novih leksema, dizajniranih leksema (maškarthemeski, manušvalikane čačipa, Arakhavne furutnenge čačipa 'međunarodna', 'ljudska prava', 'Branioci građanskih prava' ), omogućeno je izbjegavanje korištenja već ogromnog broja posuđenica iz kontakt jezika, ali je $\mathrm{i}$ u isto vrijeme dovedeno u pitanje razumijevanje sadržaja u ovisnosti od romskih govornika i čitalaca. I pored dizajn leksema ipak je evidentno korištenje još devet posuđenica i adaptiranih neologizama (konferencija, narodo, glaso, i, mora, živinen, skupo, organizirime, biprofitnikani organizacija).

Ukoliko se vodimo Samardžijinom definicijom neologizama da su ,[n]eologizmi [...] novotvorene, prevedenice, nove posuđenice i oživljenice, dakle svi leksemi koji su u određenom trenutku novi ('nepoznati') jezičkoj zajednici ili njezinu većemu dijelu“ (Samardžija 2002: 17), lekseme u primjeru 4 (maškarthemeski, manušvalikane čačipa, Arakhavne furutnenge čačipa - 'međunarodna', 'ljudska prava', 'Branioci građanskih prava') kategorišemo kao neologizme jer su to kreacije odnosno dizajni nastali korištenjem dvaju ili više romskih leksema u vremenu nove generacije romskih govornika odnosno za vrijeme njihovih života, kao prevođenje po narudžbi za potrebe određenih institucija u domenu ljudskih prava. Da li će ti leksemi ući u romski jezik i da li će se koristiti i od strane romskih prosječnih romskih govornika pokazat će vrijeme koje dolazi.

Kada je u pitanju primjer 4 B leksemi Evropako čartero, minoritetonge, eksplikacijako raporto, diferentni organur, Artiklo, non-diskriminacija nastali su iz engleskog jezika, leksemi Manušikane Čačimata iz kombinacije romskih dijalekata, dok su leksemi Fundamentalni Slobode nastali iz kombinacije engleskog i bosanskog jezika. ${ }^{38}$

Na osnovi ovakvih i sličnih primjera sasvim je jasno da govornici romskog jezika vladaju dominantnim idiomima i da je proces jezičke asimilacije daleko odmakao. Činjenica je da se jezička asimilacija reflektuje preko gubitka identiteta romske jezične zajednice pod uticajem druge/ih jezičnih zajednica, ali i da ,,(..) situacija danas izgleda kao trka između asimilacije i revitalizacije. Ključni za situaciju su

${ }^{38}$ Za primjer $4 \mathrm{~B}$ u radu korišteni prijevodi teksta Evropske povelje za regionalne ili manjinske jezike: <https://www.coe.int/en/web/european-charter-regional-or-minority-languages/text-ofthe-charter>; romski tekst - prijevod na romski jezik preuzet sa stranice 11 i $2<\mathrm{https}: / / \mathrm{rm} . c 0 c$. int/CoERMPublicCommonSearchServices/DisplayDCTMContent?documentId $=09000016806 \mathrm{~d} 3$ 5e9> a bosanski tekst - prijevod na bosanski jezik preuzet sa stranice 1 i $2<$ https://rm.coe.int explrpt-bi/16808df016> 18.02.2019. 
hronologija modernizacije, politike asimilicaje i etničke renesanse“399 (Fishman and Garcia 2010: 262)

\section{ZAKLJUČAK}

Još uvijek nema sistema niti mjera koji bi mogli značajno uticati na poboljšanje društveno-ekonomske i političke situacije Roma i njihovog jezika na prostorima južnoslavenskih naroda i njihovih jezika. ${ }^{40}$ Razmišljanja lingviste Ranka Bugarskog su da

,[s] jedne strane imamo politički unitarizam poredan sa jugoslovenskim identitetom, mekim granicama i zajedničkim srpsko-hrvatskim jezikom; $\mathrm{s}$ druge strane, politički separatizam u kombinaciji s etnonacionalnim identitetom, teškim granicama i srpskim, hrvatskim, bosanskim i crnogorskim jezicima“" (Bugarski 2012: 232).

Uticaj ovakvih politika na položaj i situaciju Roma i njihov jezik reflektiran je u rezultatu sprovedene ankete u ovom radu i u navedenim primjerima korištenja posuđenica i neologizama u svakodnevnom govoru, u pisanom radu i prevođenju kod prosječnih romskih govornika. Posuđivanje leksema iz drugih jezika, njihova adaptacija i asimilacija komponenta su rasta i razvoja romskog jezika, u kontinuitetu, a vodi konačnom uklapanju leksema iz kontakt jezika u njegove fonološke, morfološke i sintaktičke strukture.

Zbog uticaja već navedenih politika, leksemi iz kontakt jezikâ utiču i na povećanje segmentacije i/ili fragmentacije romskog jezika kako među govornicima institucijama u okviru jedne države tako i među državama u regionu. U skladu s tim bilo bi veoma korisno podržati „,mogućnost izrade elektronskog romskog rečnika (zbog) mnogih prednosti koje elektronska forma pruža, a koje bi bile od velike korist istraživačima, nastavnicima i učenicima romskog jezika“ (Љ. Ђурић 2018: 267).

Ova i slične ovoj ideje ukazuju na neophodnost istraživanja koje bi moglo i trebalo da omogući, u saradnji sa govornicima romskog jezika, proučavanje posuđenica u romskom jeziku u Bosni i Hercegovini, Hrvatskoj, Crnoj Gori i Srbiji s posebnim osvrtom na nehotično preuzimanje glasovnih, morfoloških i sintaktičkih elemenata Proučavanjem bi se ustanovilo koliko se posuđenice razlikuju u romskim govorima u navedenim državama, a istraživanje bi moglo obuhvatiti ne samo leksički nivo, već fonetsko-fonološki i morfološko-tvorbeni.

${ }^{39}$, ,...) situation today seems to be a race between assimilation and revitalisation. Cruical for the sitution has been teh chronology of modernization, assimilation politics, and ethnic renaissance“ (Fishman and Garcia 2010:262).

40 " [...] the Serbo-Croatian area experienced an administrative dismembering and multiplicaion of the formerly common language. [...] Just as Yugoslavia was no longer conceivable, so there could be no Serbo-Croatian, whose internal boundaries essentially became external: the forme variants were elevated to the rank of separate standard languages bearing national names - Serbian, Croatian and Bosnian, now also Montenegrin. Thus, one language was politically split into four, with normally insignificant existing distinctions blown up by largely artificial measures of linguistic engineering, so as to emphasise their symbolic value as firm markers of ethnic allegiance an independent statehood" (Bugarski 2012: 230).

\section{Citirana literatura}

Acković, Dragoljub (ed.). „Antologija romske poezije“. Sarajevske sveske 39-40. Sarajevo: Sarajevske sveske, 2012, 408

Boretzky, Norbert and Brigit Igla. Wörterbuch Romani-Deutsch-English für den südosteuropäischen Raum mit einer Grammatik der Dialektvarianten. Wiesbaden: Harrassowitz Verlag, 1994.

Bugarski, Ranko. "Language, identity and borders in the former Serbocroatian area". Journal of Multilingual and Multicultural Development 33/3, 2012, 219-235.

Ćirković, Svetlana i Mirić, Mirjana. Romsko-srpski rečnik knjaževačkog gurbetskog govora. Edicija Knjaževačkim krajem, knjiga 8. Knjaževac: Narodna biblioteka „Njegoš“, 2017.

Demir, Ljatif. Književni i jezički aspekti kulture Roma Jerlija u Makedoniji. Zagreb: Sveučilište u Zagrebu, Filozofski fakultet. Doktorska disertacija, 2017. <http://darhiv. ffzg.unizg.hr/id/eprint/9049/1/doktorski\%20rad\%20ljatif\%20demir\%20final.pdf > 20.12.2018.

Đurić, Rajko. Standardizacija romskog jezika. Sarajevo: Romski informativni centar „Kali Sara“, 2012.

European Charter for Regional or Minority Languages. $<$ https://rm.coe.int $/ 168007 \mathrm{bf} 4 \mathrm{~b}>$ 14.01.2019.

Filipović, Rudolf. Teorija jezika u kontaktu. Zagreb: JAZU - Školska knjiga, 1986.

Fishman, Joshua and Garcia, Ofelia (eds.). Handbook of Language and Ethnic Identity. Volume 1, Second edition, Disciplinary and regional perspectives. New York: Oxford University Press, 2010.

Hancock, Ian. We are the Romani people/Amen sam e Rromane džene. Hertfordshire: Centre de Recherches Tsiganes, University of Hertfordshire Press, 2002.

Hancock, Ian."Mind the Doors! The contribution of linguistics" in All Change! Roman Studies through Romani eyes. Hertfordshire: University of Hertfordshire Press, 2010

Lee, Ronald. Rromano, Alavari: Kalderashitska-Inglezitska/Romani Dictionary: Kalderash-English. Toronto: Magoria Books, 2010.

Matras, Yaron. Romani: A Linguistic Introduction. Cambridge: Cambridge University Press, 2002.

Miklosich, Franz. Beiträge zur Kenntniss der Mundart der Zigeuner in Galizien, in Sirmien und in Serbien. Mit einem Anhange über den Ursprung des Names „Zigeuner“. Vorgelegt in der Sitzung am 9. Februar 1876. [U] Denkschriften der Keiserlichen Akademie der Wissenschaften. Philosophisch-Historische Classe. Sechsundzwanzigster Band Wien: In Commision bei Karl Gerolds Sohn: Buchhändler der Keis. Akademie der Wiesenschaften, 1877.

Samardžija, Marko. Nekoć i nedavno. Odabrane teme iz leksikologije i novije povijesti hrvatskoga standardnoga jezika. Rijeka: Izdavački centar, 2002.

Tahirović-Sijerčić, Hedina. Language and literature of Roma within translation in the Western Balkans: Poetry in self-translation (Jezik i književnost Roma u prevodu na Zapadnom Balkanu: Poezija u autoprevodu. Belgrade: University of Belgrade, Faculty of Philology. Doctoral dissertation, 2018b.

$<$ https://uvidok.rcub.bg.ac.rs/bitstream/handle/123456789/2767/Doktorat.pdf?sequence $=1 \&$ is Allowed $=\mathrm{y}>10.01 .2019$.

Славистика XXIII/1 (2019) 
Tahirović-Sijerčić, Hedina. „Translation and Translators in Romani Context“. Journal of Education and Humanities. Volume 1 (2), Sarajevo: Faculty of Education and Humanities, Internatinal Burch University, Winter 2018c, 126-142.

$<$ https://www.ibu.edu.ba/assets/userfiles/jeh/JEH_winter_2018/jeh_volume_1_issue_2. $\mathrm{pd}>19.02 .2019$

Tahirović-Sijerčić, Hedina. Čuj, osjeti bol!/Ashun, hachar dukh! Sarajevo: Književni krug - KNS, 2010.

Toninato, P. The Rise of Written Literature among the Roma: A Study of the Role of Writing in the Current Re-Definition of Romani Identity with Specific Reference to the Italian Case. University of Warwick: Centre for Translation and Comparative Cultural Studies. Doctoral Thesis, 2004.

$<$ http://wrap.warwick.ac.uk/1224/1/WRAP_THESIS_Toninato_2004.pdf $>$ 21.01.2019.

Uhlik, Rade. Srpskohrvatski ciganski rečnik (Romane alava). Sarajevo: Svjetlost, 1947.

Uhlik, Rade. Srpskohrvatsko-Romsko-Engleski rječnik/Romengo Alavari. Sarajevo: OOUR Izdavačka djelatnost Svjetlost, 1983.

Vajzović, Hanka. Orijentalizmi u književnom djelu: lingvistička analiza. Sarajevo: Institut za jezik i Orijentalni institut, 1999.

Zatreanu, Mihaela and Dieter W. Halwachs. Romani in Europe. Bucharest: Ministry of Education and Research/Department of Linguistics at the University of Graz, 2003.

$<$ http://www.coe.int/t/dg4/education/roma/Source/RomaniEurope EN.pdf > 10.01.2019.

Ђурић, Љубица. „Ромолошка лексикографија у Србији: стање и доступност“. [У: Т. Варади, Б. Сикимић (ур.) Очување, заштита и перспективе ромског језика Зборник радова са научног скупа одржаног 20-21. октобра 2016. Београд: Српска академија наука и уметности (САНУ), 2018, 253-270.

Ђурић, Рајко. „Ромски модални глаголи, нека отворена питања“. [У:] Т. Варади, Б. Сикимић (ур.). Очување, заштита и перспективе ромског језика. Зборник радова са научног скупа одржаног 20-21. октобра 2016. Београд: Српска академија наука и уметности (САНУ), 2018, 271-282.

Сикимић, Биљана."Франц Миклошич и ромологија“. [У:] Ј. Грковић-Мејџор, А Лома (ур.). Зборник у част двестоте годишњице рођења Франца Миклошича Београд: САНУ, Посебна издања 674, 2013, 435-454.

Тахировић-Сијерчић, Хедина. „Могућности очувања лингвистичке виталности ромског језика“. [У:] Т. Варади, Б. Сикимић (ур.). Очување, заштита и перспективе ромског језика. Зборник радова са научног скупа одржаног 20-21. октобра 2016. Београд: Српска академија наука и уметности (САНУ), 2018a, 111-130.
Hedina Tahirović-Sijerčić

\section{SOUTH SLAVIC LOANWORDS IN ROMANI LANGUAGE}

Resume

This work, for the first time in the regions of the former Yugoslavia, speaks about South Slavic borrowers in the Romani language. In the introductory part of this paper, I refer to the migration of Roma as well as to borrowers and neologisms in the Romani language from the languages with which Roma were the longest in contact. Claims by well-known researchers in the area of Romani language (Hancock, Lockwood) that Balkan languages and Slavic languages have the most influence to Ro (he Slavic lan of two-step senatic adp results of a survey in this paper and examples from everyday practice, in the written word an translation, I justify my claim that the borrowers and neologisms from the South Slavic language not only influence the preservation of the linguistic vitality of the Romani language, but also they lead to the loss of its distinctivness.

Facilitating the research on Romani language and on borrowers and neologisms in the Romani language will help understanding the differences and similarities of not only Romani dialects in the region but also of contact languages in the region. However, one should not forget that de facto protection of Romani language also requires de facto protection of the cultural, economic, political and educational status of Roma.

Key words: loanwords, neologisms, Romani language, hybrid, contact langauge effect. 